\title{
Mesorhizobium olivaresii sp. nov. isolated from Lotus corniculatus nodules
}

María J. Lorite ${ }^{1}$, José David Flores-Félix ${ }^{2}$, Álvaro Peix ${ }^{3,4}$, Juan Sanjuán ${ }^{1}$, Encarna Velazquez ${ }^{2,3 *}$

1. Departamento de Microbiología del Suelo y Sistemas Simbióticos. Estación Experimental del Zaidin. CSIC. Granada. Spain.

2 Departamento de Microbiología y Genética. Universidad de Salamanca. Salamanca. Spain

3 Unidad Asociada Universidad de Salamanca-CSIC "Interacciones PlantaMicroorganismo".

4 IRNASA-CSIC. Salamanca. Spain.

Running title: Mesorhizobium olivaresii sp. nov.

Journal's content category: New Taxa-Proteobacteria

Keywords: Mesorhizobium, Lotus corniculatus, Spain

Accession numbers for type strain of Mesorhizobium olivaresii:

16S rRNA gene: FM203302

recA gene: FN556460

glnII gene: LN681554

atpD gene: FM203309

rpoB gene: KX712097

nodC gene: FM203320 


\begin{abstract}
In this study four Mesorhizobium strains isolated from Lotus corniculatus nodules in Granada (Spain) were characterized. Their 16S rRNA gene sequences were closely related to those of $M$. albiziae LMG $23507^{\mathrm{T}}$ and $M$. chacoense $\operatorname{Pr} 5^{\mathrm{T}}$ showing 99.4 and 99.2\% similarity values, respectively. The analysis of concatenated $r p o B, \operatorname{rec} A$, atpD and $g \ln I I$ genes showed they formed a cluster with internal similarities higher than $97 \%$. The closest species also were M. albiziae LMG $23507^{\mathrm{T}}$ and $M$. chacoense $\operatorname{Pr} 5^{\mathrm{T}}$ showing similarity values lower than $92 \%$ in $r p o B$, recA and $g \ln I I$ genes and lower than $96.5 \%$ in the $\operatorname{atpD}$ gene. These results indicated that the L. corniculatus strains belong to a new species of genus Mesorhizobium which was confirmed by DNA-DNA hybridization and phenotypic characterization. Therefore a new species with the name Mesorhizobium olivaresii sp. nov. is proposed, and the type strain is $\mathrm{CPS}_{13} 3^{\mathrm{T}}\left(\mathrm{LMG} 29295^{\mathrm{T}}=\mathrm{CECT}\right.$ $\left.9099^{\mathrm{T}}\right)$.
\end{abstract}


The genus Mesorhizobium was proposed by Jarvis et al. [7] to accomodate several species phylogenetically divergent to those from genus Rhizobium and currently contains more than 30 species with Mesorhizobium loti as the type species of the genus (http://www.bacterio.net/mesorhizobium.html). The type strain of this species was deposited in several collections and recently it has been reported that those conserved in ATCC and USDA collections belonged to different species which have been named Mesorhizobium erdmanii and Mesorhizobium jarvisii [14]. All these species are endosymbionts of Lotus corniculatus, a legume worldwide distributed that establishes symbiosis with strains from genus Mesorhizobium in America [2, 16, 23], Europe [1, 4, $6,10,12]$, Asia $[7,21]$ and Oceania $[17,24]$.

Some strains isolated in different continents from L. corniculatus nodules belong to groups phylogenetically divergent to the currently described species of genus Mesorhizobium as was showed by Marcos et al. [12]. One of these groups contained some strains isolated in Granada (Spain) from L. corniculatus during a wide study of Lotus spp. endosymbionts [10]. The objective of the present work was to perform a polyphasic characterization of these strains and the proposal of a novel species named Mesorhizobium olivaresii sp. nov.

In this work we obtained for the strains CPS13 ${ }^{\mathrm{T}}, \mathrm{CPS} 1, \mathrm{CGS} 20$ and CGS22 the $16 \mathrm{~S}$ rRNA, atpD, $\operatorname{rec} A, g \ln I I$ and $\operatorname{nod} C$ gene sequences not previously obtained according the methodologies of Lorite et al. [10] and Turner and Young [27]. The amplification and sequencing of the $r р о B$ gene was performed according to Martens et al. [13]. All these sequences were aligned with those of the Mesorhizobium species using the Clustal W program [26]. The distances were calculated according to Kimura's two-parameter model [8]. The phylogenetic trees were inferred using the neighbour joining (NJ) and maximum likelihood (ML) models [19, 20]. MEGA5.0 [25] was used for all analyses.

The 16S rRNA gene sequences of strains CPS13 ${ }^{\mathrm{T}}, \mathrm{CPS} 1, \mathrm{CGS} 20$ and CGS22 are identical and then only that of the strain $\mathrm{CPS} 3^{\mathrm{T}}$ was included in the NJ and ML phylogenetic analyses (Fig. 1). The results of these analyses showed that the strain $\mathrm{CPS}_{13}{ }^{\mathrm{T}}$ groups with M. albiziae CCBAU $61158^{\mathrm{T}}$ and M. chacoense $\operatorname{Pr} 5^{\mathrm{T}}$. These strains presented similarity values of $99.4 \%$ and $99.2 \%$, respectively, with respect to the strain $\mathrm{CPS}_{13}{ }^{\mathrm{T}}$. These high similarity values in the $16 \mathrm{~S}$ rRNA gene sequences is a common finding among species of genus Mesorhizobium that are distinguishable by the analysis of housekeeping genes, from which $r p o B$, recA, atpD and glnII genes are available for most species of genus Mesorhizobium. 
The NJ and ML analyses of the concatenated rpoB, recA, atpD and $g \ln I I$ genes showed internal similarities higher than $97 \%$ in the analysed genes. This cluster was related to M. chacoense $\operatorname{Pr} 5^{\mathrm{T}}\left(\mathrm{LMG} 19008^{\mathrm{T}}\right.$, ICMP14587 $\left.{ }^{\mathrm{T}}\right)$ and M. albiziae LMG $23507^{\mathrm{T}}$ with similarity values lower than $92 \%$ in rpoB, recA and $g \ln I I$ genes and lower than $96.5 \%$ in the atpD gene. The results of the phylogenetic analyses indicated that the strains $\mathrm{CPS}_{13}{ }^{\mathrm{T}}$, CPS1, CGS20 and CGS22 belong to a new species of genus Mesorhizobium since the distances found between the strains of this species and the remaning ones of this genus are higher than those found among most of the currently described Mesorhizobium species (Fig. 2).

This was confirmed by DNA-DNA hybridization experiments carried out following the method of Ezaki et al. [5] with the recommendations of Willems et al. [29]. The strain $\mathrm{CPS}_{13} 3^{\mathrm{T}}$ was hybridized with M. albiziae LMG $23507^{\mathrm{T}}$ and $M$. chacoense $\operatorname{Pr} 5^{\mathrm{T}}$ showing $50 \%( \pm 9 \%)$ and 54\% ( $\pm 6 \%)$ DNA-DNA relatedness, respectively. Both values are lower than the threshold value of $70 \%$ DNA-DNA similarity for definition of bacterial species [28] supporting that the L. corniculatus strains isolated in Granada belong to a new species of genus Mesorhizobium.

DNA for analysis of DNA base composition was prepared according to Chun and Goodfellow [3]. The mol \% G+C content of DNA was determined using the thermal denaturation method [11]. The $\mathrm{G}+\mathrm{C}$ content of strain $\mathrm{CPS} 13^{\mathrm{T}}$ was $62.7 \mathrm{~mol} \%$.

The cellular fatty acids were analysed by using the Microbial Identification System (MIDI; Microbial ID) Sherlock 6.1 and the library RTSBA6 according to the technical instructions provided by this system [22]. The strains were cultured aerobically on TY plates at $28^{\circ} \mathrm{C}$ and cells were collected after $48 \mathrm{~h}$ incubation. The major fatty acids of strain $\mathrm{CPS}_{13}{ }^{\mathrm{T}}$ are summed feature $8\left(\mathrm{C}_{18: 1} \omega 7 \mathrm{c} / \mathrm{C}_{18: 1} \omega 6 \mathrm{c}\right)$ and $\mathrm{C} 18: 1 \omega 7 \mathrm{c} 11$-methyl as in their closest related Mesorhizobium species (Table 1).

The phenotypic characterization was performed using API 20NE and API ID32GN galleries inoculated according to the manufacturer's instructions and adding sterile $\mathrm{MgSO}_{4} .7 \mathrm{H}_{2} \mathrm{O}$ to the supplied medium up to a concentration of $0.2 \mathrm{gl}^{-1}$ with the aid of a disposable Pasteur pipette. The results were read after 7 days incubation. Growth temperature range was determined by incubating cultures in Yeast Mannitol Agar (YMA) medium at $4,15,28,37$ and $45^{\circ} \mathrm{C}$. Growth $\mathrm{pH}$ range was determined in the same medium with final $\mathrm{pH} 4.0,6,7,8,9$ and 10. Salt tolerance was tested in the same medium containing $0.5,1,1.5,2$ and $2.5 \%(\mathrm{w} / \mathrm{v}) \mathrm{NaCl}$. To test the natural antibiotic 
resistance, the disc diffusion method on YMA medium was used. The discs contained the following antibiotics: ampicillin $(2 \mu \mathrm{g})$, erythromycin $(2 \mu \mathrm{g})$, ciprofloxacin $(5 \mu \mathrm{g})$, penicillin (10 IU), polymyxin (300 IU), cloxacillin (1 $\mu \mathrm{g})$, oxytetracycline (30 $\mu \mathrm{g})$, gentamycin $(10 \mu \mathrm{g})$, cefuroxime $(30 \mu \mathrm{g})$, netilmicin $(30 \mu \mathrm{g})$ and neomycin $(5 \mu \mathrm{g})$, (Becton Dickinson, BBL). The type strains of $M$. albiziae LMG $23507^{\mathrm{T}}$ and $M$. chacoense $\operatorname{Pr} 5^{\mathrm{T}}$ were included in the phenotypic study as reference. Phenotypic characteristics of the new species are reported below in the species description and the differences with respect to the closest species of Mesorhizobium are recorded in Table 2.

Despite symbiotic genes do not offer taxonomic information because they are located in easily interchangeable elements (plasmids or symbiotic islands), the analysis of the nodC gene sequences allowed the identification of strains at symbiovar level $[15,18]$. Rhizobial symbiovars are constituted by different symbiotic groups within a single species [18] that in the case of genus Mesorhizobium have been described on the basis of the nodC gene phylogenetic analyses [9]. In the previous work of Lorite et al. [10] the nodC gene of the type strain CPS13 ${ }^{\mathrm{T}}$ was analysed showing that it belongs to the same symbiovar that the type strain of $M$. loti LMG $6125^{\mathrm{T}}\left(\mathrm{NZP} 2213^{\mathrm{T}}\right)$. In this work we analysed the other strains from the new species M. olivaresii CPS1, CGS20 and CGS22 showing that they were phylogenetically related to the strain $\mathrm{CPS}_{13}^{\mathrm{T}}$ after the nodC gene NJ and ML phylogenetic analyses (Fig. 3). These results confirmed that the strains isolated in Granada from L. corniculatus belong to the symbiovar loti, although they belong to a cluster phylogenetically divergent to those formed by the type strains of other Mesorhizobium species nodulating this host, particularly M. jarvisii (Fig. 3).

The results from the phylogenetic analyses of core genes, DNA-DNA hybridization experiments and phenotypic and chemotaxonomic characterization showed that the strains isolated from L. corniculatus nodules in Granada (Spain) represent a novel species for which we propose the name Mesorhizobium olivaresii sp. nov.

\section{Description of Mesorhizobium olivaresii sp. nov.}

Mesorhizobium olivaresii (o.li.va.res'i.i N.L. masc. gen. n. olivaresii to honour José Olivares, Spanish microbiologist, for his valuable contributions in rhizobial research).

Gram-negative, aerobic rods as for the other species of the genus. Colonies on YMA are white, circular and convex with diameter of $1-2 \mathrm{~mm}$ within $4-5$ days at $28^{\circ} \mathrm{C}$. It grows 
from $15^{\circ} \mathrm{C}$ to $37^{\circ} \mathrm{C}$ and optimally at $28^{\circ} \mathrm{C}$. The $\mathrm{pH}$ range for growth is 6.5 to 8 with optimum growth at $\mathrm{pH} 7$. They grow up to $1.5 \% \mathrm{NaCl}$. Nitrate reduction, arginine dehydrolase and gelatinase were negative and urease and $\beta$-galactosidase were positive. Esculin hydrolysis was positive. Assimilation of glucose, L-arabinose, L-rhamnose, Dribose, L-fucose, D-mannose, mannitol, inositol, D-sorbitol, maltose, sucrose, melibiose, valerate, 3-hydroxi-butyrate, L-histidine and L-proline was positive. Assimilation of salicin, gluconate, caprate, adipate, citrate, phenylacetate itaconate, suberate, malonate, 2 keto-gluconate, glycogen, 3 and 4 hydroxi-benzoate and L-serine was negative. Assimilation of $\mathrm{N}$-acetyl-glucosamine, malate and $\mathrm{D}, \mathrm{L}-$ lactate was variable. Acetate, L-alanine, 5 keto-gluconate and propionate were weakly assimilated. Sensitive to neomycin, gentamycin, netilmycin and tetracyclin and resistant to ampicillin, cefuroxime, cloxacillin, penicillin, and erythromycin. Variable results were found in the case of cyprofloxacin and polymyxin B. $\mathrm{G}+\mathrm{C}$ content was $62.7 \mathrm{~mol} \%$. The type strain $\mathrm{CPS}_{13}^{\mathrm{T}}\left(=\mathrm{LMG} 29295^{\mathrm{T}}=\mathrm{CECT} 9099^{\mathrm{T}}\right)$ was isolated from root nodules of Lotus corniculatus.

\section{Acknowledgements}

This work was supported by the EU-INCO project LOTASSA (J.S.) and Junta de Andalucía (Spain). JDFF is recipient of a predoctoral fellowship from Universidad de Salamanca. 


\section{References}

[1] Ampomah, O.Y., Huss-Danell, K. (2011) Genetic diversity of root nodule bacteria nodulating Lotus corniculatus and Anthyllis vulneraria in Sweden. Syst. Appl. Microbiol. 34, 267-275.

[2] Binde, D.R., Menna, P., Bangel, E.V., Barcellos, F.G., Hungria, M. (2009) Rep-PCR fingerprinting and taxonomy based on the sequencing of the $16 \mathrm{~S}$ rRNA gene of 54 elite commercial rhizobial strains. Appl. Microbiol. Biotechnol. 83, 897-908.

[3] Chun, J., Goodfellow, M. (1995) A phylogenetic analysis of the genus Nocardia with 16S rRNA sequences. Int. J. Syst. Bacteriol. 45, 240-245.

[4] De Meyer, S.E., Van Hoorde, K., Vekeman, B., Braeckman, T., Willems A. (2011) Genetic diversity of rhizobia associated with indigenous legumes in different regions of Flanders (Belgium). Soil Biol. Biochem. 43, 2384-2396.

[5] Ezaki, T., Hashimoto, Y., Yabuchi, E. (1989) Fluorometric deoxyribonucleic aciddeoxyribonucleic acid acid hybridization in microdilution wells as an alternative to membrane filter hybridization in which radioisotopes are used to determine genetic relatedness among bacterial strains. Int. J. Syst. Bacteriol. 39, 224-229.

[6] Gossmann, J.A., Markmann, K., Brachmann, A., Rose, L.R., Parniske, M. (2012) Polymorphic infection and organogenesis patterns induced by a Rhizobium leguminosarum isolate from Lotus root nodules are determined by the host genotype. New Phytologist. 196 ,561-573.

[7] Jarvis, B.D.W., van Berkum, P., Chen, W.X., Nour, S.M., Fernandez, M.P., CleyetMarel, J.C., Gillis, M. (1997) Transfer of Rhizobium loti, Rhizobium huakuii, Rhizobium ciceri, Rhizobium mediterraneum, and Rhizobium tianshanense to Mesorhizobium gen. nov. Int. J. Syst. Bacteriol. 47, 895-898. 
[8] Kimura, M. (1980) A simple method for estimating evolutionary rates of base substitutions through comparative studies of nucleotide sequences. J. Mol. Evol. 16, 111-120.

[9] Laranjo, M., Alexandre, A., Oliveira, S. (2014) Legume growth-promoting rhizobia: an overview on the Mesorhizobium genus. Microbiol. Res. 169:2-17.

[10] Lorite, M.J., Muñoz, S., Olivares, J., Soto, M.J., Sanjuán, J. (2010) Characterization of strains unlike Mesorhizobium loti that nodulate Lotus spp. in saline soils of Granada, Spain. Appl. Environ. Microbiol. 76, 4019-4026.

[11] Mandel, M., Mamur, J. (1968) Use of ultraviolet absorbance temperature profile for determining the guanine plus cytosine content of DNA. Methods Enzymol. 12B, 195-206.

[12] Marcos-García, M., Menéndez, E., Cruz-González, X., Velázquez, E., Mateos, P.F., Rivas, R. (2015) The high diversity of Lotus corniculatus endosymbionts in soils of Northwest Spain. Symbiosis 67, 11-20.

[13] Martens, M., Dawyndt, P., Coopman, R., Gillis, M., De Vos, P., Willems, A. (2008) Advantages of multilocus sequence analysis for taxonomic studies: a case study using 10 housekeeping genes in the genus Ensifer (including former Sinorhizobium). Int. J. Syst. Evol. Microbiol. 58: 200-214.

[14] Martínez-Hidalgo, P., Ramírez-Bahena, M.H,, Flores-Félix, J.D., Rivas, R., Igual, J.M., Mateos, P.F., Martínez-Molina, E., León-Barrios, M., Peix, Á., Velázquez, E. (2015) Revision of the taxonomic status of type strains of Mesorhizobium loti and reclassification of strain USDA $3471^{\mathrm{T}}$ as the type strain of Mesorhizobiumerdmanii sp. nov. and ATCC $33669^{\mathrm{T}}$ as the type strain of Mesorhizobiumjarvisii sp. nov. Int. J. Syst. Evol. Microbiol. 65:1703-1708.

[15] Peix, A., Ramírez-Bahena, M.H., Velázquez, E., Bedmar, E.J. (2015) Bacterial associations with legumes. Crit. Rev. Plant Sci. 34, 17-42. 
[16] Qian, J., Parker, M.A. (2002) Contrasting nifD and ribosomal gene relationships among Mesorhizobium from Lotus oroboides in northern Mexico. Syst. Appl. Microbiol. 25, 68-73.

[17] Reeve, W., Sullivan, J., Ronson, C., Tian, R., Bräu, L., Davenport, K., Goodwin, L., Chain, P., Woyke, T., Lobos, E., Huntemann, M., Pati, A., Mavromatis, K., Markowitz, V., Ivanova, N., Kyrpides, N. (2014) Genome sequence of the Lotus corniculatus microsymbiont Mesorhizobium loti strain R88B. Stand. Genomic Sci. 9, 3.

[18] Rogel, M.A., Ormeño-Orrillo, E., Martinez-Romero, E. (2011) Symbiovars in rhizobia reflect bacterial adaptation to legumes. Syst. Appl. Microbiol. 34, 96-104.

[19] Rogers, J.S., Swofford, D.L. (1998) A fast method for approximating maximum likelihoods of phylogenetic trees from nucleotide sequences. Syst. Biol. 47, 77-89.

[20] Saitou, N., Nei, M. (1987) A neighbour-joining method: a new method for reconstructing phylogenetics trees. Mol. Biol. Evol. 44, 406-425.

[21] Saeki, K., Kouchi H. (2000) The Lotus symbiont, Mesorhizobium loti: molecular genetic techniques and application. J. Plant Res. 113, 457-465.

[22] Sasser, M. (1990) Identification of bacteria by gas chromatography of cellular fatty acids, MIDI Technical Note 101. Newark, DE: MIDI Inc.

[23] Sotelo, M., Irisarri, P., Lorite, M.J., Casaretto, E., Rebuffo, M., Sanjuán, J., Monza, J. (2011) Diversity of rhizobia nodulating Lotus corniculatus grown in northern and southern regions of Uruguay. Appl. Soil Ecol. 49,197-207.

[24] Sullivan, J.T., Patrick, H.N., Lowther, W.L., Scott, D.B., Ronson, C.W. (1995) Nodulating strains of Rhizobium loti arise through chromosomal symbiotic gene transfer in the environment. Proc. Natl. Acad. Sci. USA 92, 8985-8989.

[25] Tamura, K., Peterson, D., Peterson, N., Stecher, G., Nei, M., Kumar, S. (2011) MEGA5: Molecular Evolutionary Genetics Analysis using Maximum Likelihood, 
Evolutionary Distance, and Maximum Parsimony Methods. Mol. Biol. Evol. 28, 27312739.

[26] Thompson, J.D., Gibson, T.J., Plewniak, F., Jeanmougin, F., Higgins, D.G. (1997) The CLUSTAL_X Windows interface: flexible strategies for multiple sequence alignment aided by quality analysis tools. Nucleic Acids Res. 25, 4876-4882.

[27] Turner, S.L., Young, J.P.W. (2000) The glutamine synthetases of rhizobia: phylogenetics and evolutionary implications. Mol. Biol. Evol.17, 309-319.

[28] Wayne, L.G., Brenner, D.J., Colwell, R.R., Grimont, P.A.D., Kandler, O., Krichevsky, M.I., Moore, L.H., Moore, W.E.C., Murray, R.G.E., Stackebrandt, E., Starr, M.P., Trüper, H.G. (1987) Report of the ad hoc committee on reconciliation of approaches to bacterial systematics. Int. J. Syst. Bacteriol. 37, 463-464.

[29] Willems, A., Munive, A., de Lajudie, P., Gillis, M. (2003) In most Bradyrhizobium groups sequence comparison of $16 \mathrm{~S}-23 \mathrm{~S}$ rDNA internal transcribed spacer regions corroborates DNA-DNA hybridizations. Syst. Appl. Microbiol. 26, 203-210. 


\section{Figure legends}

Figure 1. Neighbour-joining phylogenetic tree based on 16S rRNA gene sequences (1270 nucleotides) showing the position of Mesorhizobium olivaresii $\mathrm{CPS}_{13}^{\mathrm{T}}$ within genus Mesorhizobium. Bootstrap values calculated for 1000 replications are indicated. Bar, 1 nt substitution per 100 nt. The nodes marked with filled circles were also obtained with the maximum likelihood algorithm.

Figure 2. Neighbour-joining phylogenetic tree based on concatenated $r e c A$ and $g \ln I I$ gene sequences (2000 nucleotides) showing the position of Mesorhizobium olivaresii strains within genus Mesorhizobium. Bootstrap values calculated for 1000 replications are indicated. Bar, $1 \mathrm{nt}$ substitution per $100 \mathrm{nt}$. The nodes marked with filled circles were also obtained with the maximum likelihood algorithm.

Figure 3. Neighbour-joining phylogenetic tree based on nodC gene sequences (390 positions) showing the position of Mesorhizobium olivaresii strains within genus Mesorhizobium. Bootstrap values calculated for 1000 replications are indicated. Bar, 2 nt substitution per $100 \mathrm{nt}$. The nodes marked with filled circles were also obtained with maximum the likelihood algorithm. 
Table 1. Cellular fatty acid composition of M. olivaresii $\mathrm{CPS}_{13} 3^{\mathrm{T}}$ and its most closely related species $M$. albiziae LMG $23507^{\mathrm{T}}$ and $M$. chacoense $\operatorname{Pr} 5^{\mathrm{T}}$, and the type strain of the type species of the genus Mesorhizobium, M. loti NZP $2213^{\mathrm{T}}$.

Strains: 1, M. olivaresii sp. nov. CPS13 ${ }^{\mathrm{T}} ; 2$, M. albiziae LMG $23507^{\mathrm{T}}$; 3, M. chacoense $\operatorname{Pr} 5^{\mathrm{T}}$; 4, M. loti NZP $2213^{\mathrm{T}}$. Fatty acids present in amounts lower than $1 \%$ are not shown. nd, not detected. Data are from this study.

\begin{tabular}{lcccc}
\hline Characteristics & 1 & 2 & 3 & 4 \\
$\mathrm{C}_{16: 0}$ & 3.4 & 5.1 & 5.3 & 12.1 \\
$\mathrm{C}_{17: 0}$ & 3.3 & 0.8 & 2.1 & 1.4 \\
$\mathrm{C}_{18: 0}$ iso & 2.7 & 3.1 & 4.7 & 5.6 \\
$\mathrm{C}_{15: 0}$ iso & 2.9 & 6.4 & 2.9 & $\mathrm{nd}$ \\
$\mathrm{C}_{15: 0}$ iso $3 \mathrm{OH}$ & 3.3 & 2.2 & 4.6 & $\mathrm{nd}$ \\
$\mathrm{C}_{17: 0}$ iso & 5.7 & 5.1 & 8.2 & 4.6 \\
$\mathrm{C}_{17: 1} \omega 8 \mathrm{c}$ & 3.4 & 0.4 & 1.2 & $\mathrm{nd}$ \\
summed feature $3\left(\mathrm{C}_{16: 1} \omega 7 \mathrm{c} /\right.$ & 2.3 & 1.5 & 1.1 & $\mathrm{nd}$ \\
$\left.\mathrm{C}_{16: 1} \omega 6 \mathrm{c}\right)$ & & & & \\
summed feature 8 $\left(\mathrm{C}_{18: 1} \omega 7 \mathrm{c} /\right.$ & 37.6 & 62.8 & 40.3 & 43.6 \\
$\left.\mathrm{C}_{18: 1} \omega 6 \mathrm{c}\right)$ & & & & \\
$\mathrm{C}_{18: 1} \omega 7 \mathrm{c} 11-\mathrm{s}$-methyl & 24.0 & 11.1 & 19.9 & 16.0 \\
$\mathrm{C}_{19: 0}$ cyclo $\omega 8 \mathrm{c}$ & 8.8 & 0.4 & 8.5 & 16.3 \\
\hline
\end{tabular}


Table 2. Phenotypic differences between the new species $M$. olivaresii and its most closely related species $M$. albiziae LMG $23507^{\mathrm{T}}$ and $M$. chacoense Pr5 ${ }^{\mathrm{T}}$, and the type strain of the type species of the genus Mesorhizobium, M. loti NZP $2213^{\mathrm{T}}$.

Strains: 1, M. olivaresii sp. nov. CPS13 ${ }^{\mathrm{T}} ; 2$, M. olivaresii sp. nov. CPS1; 3, M. olivaresii sp. nov. CGS20; 4, M. olivaresii sp. nov. CGS22; 5, M. albiziae LMG 23507 ${ }^{\mathrm{T}}$; 6, M. chacoense $\operatorname{Pr} 5^{\mathrm{T}}$; 7, M. loti NZP $2213^{\mathrm{T}}$. +: positive, -: negative, w: weak. Data are from this study.

\begin{tabular}{|c|c|c|c|c|c|c|c|}
\hline & 1 & 2 & 3 & 4 & 5 & 6 & 7 \\
\hline \multicolumn{8}{|l|}{ Characteristics } \\
\hline Growth at $37^{\circ} \mathrm{C}$ & + & + & + & + & + & - & - \\
\hline Growth in presence $2 \% \mathrm{NaCl}$ & - & - & - & - & + & + & - \\
\hline \multicolumn{8}{|l|}{ Hydrolysis of: } \\
\hline PNP- $\beta$-L-arabinopyranoside & - & - & - & - & + & + & + \\
\hline PNP- $\alpha$-D-maltopyranoside & - & - & - & - & + & + & - \\
\hline PNP- $\alpha$-D-mannopyranoside & - & - & - & - & - & + & - \\
\hline PNP- $\beta$-D-mannopyranoside & - & - & - & - & - & + & - \\
\hline \multicolumn{8}{|l|}{ Assimilation of (API ID32GN): } \\
\hline Malate & - & - & w & + & + & + & - \\
\hline $\mathrm{N}$-acetyl-glucosamine & - & + & + & + & + & + & + \\
\hline \multicolumn{8}{|l|}{ Assimilation of (API ID32GN): } \\
\hline Valerate & + & + & + & + & + & - & $\mathrm{W}$ \\
\hline D,L-lactate & + & - & + & + & + & + & $\mathrm{w}$ \\
\hline Alanine & - & - & - & - & + & - & - \\
\hline Melibiose & + & + & + & + & + & - & + \\
\hline \multicolumn{8}{|l|}{ Resistance to: } \\
\hline Netilmicin & - & - & - & - & + & - & + \\
\hline Penicillin & + & + & + & + & + & - & + \\
\hline
\end{tabular}




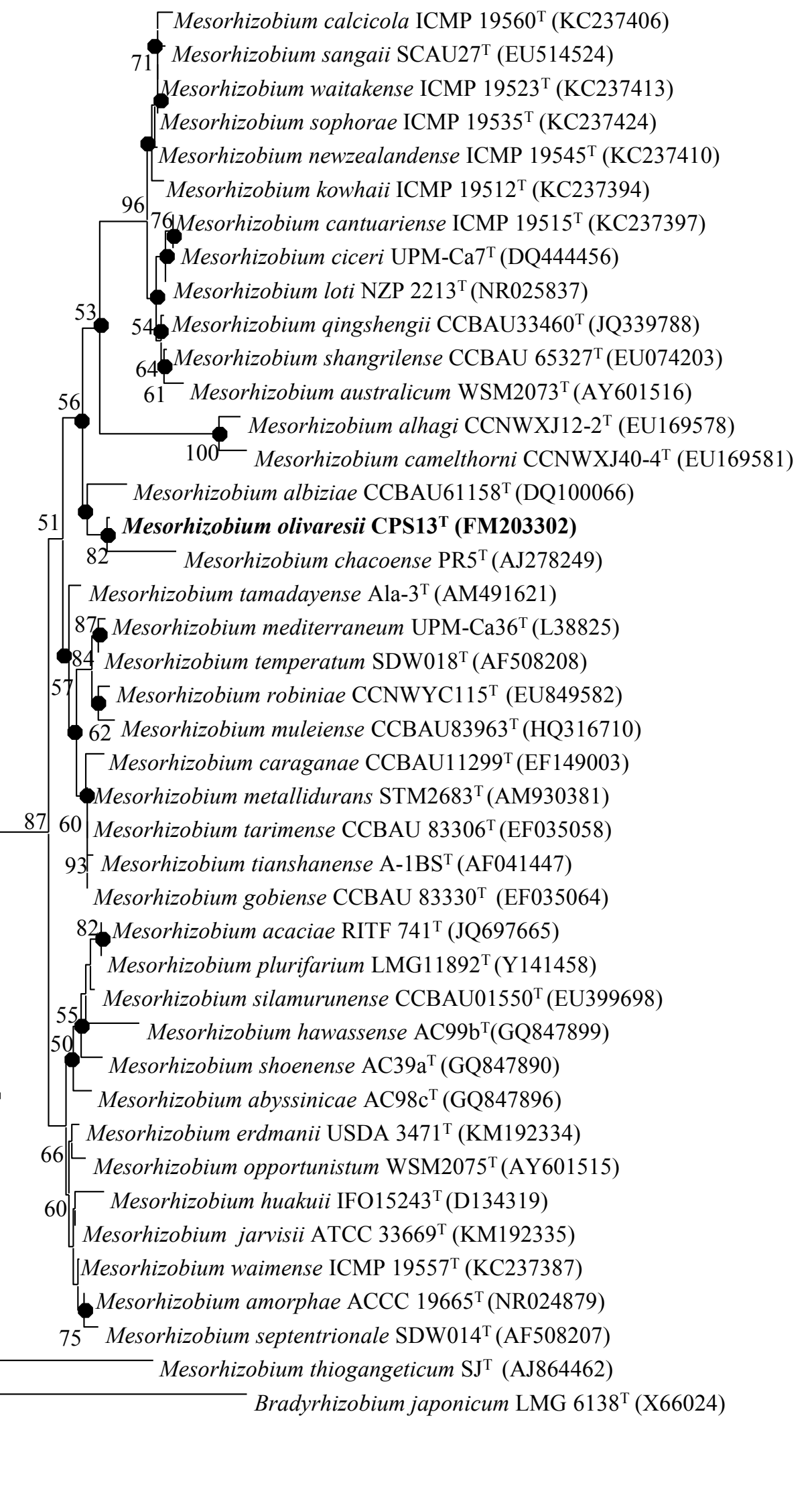




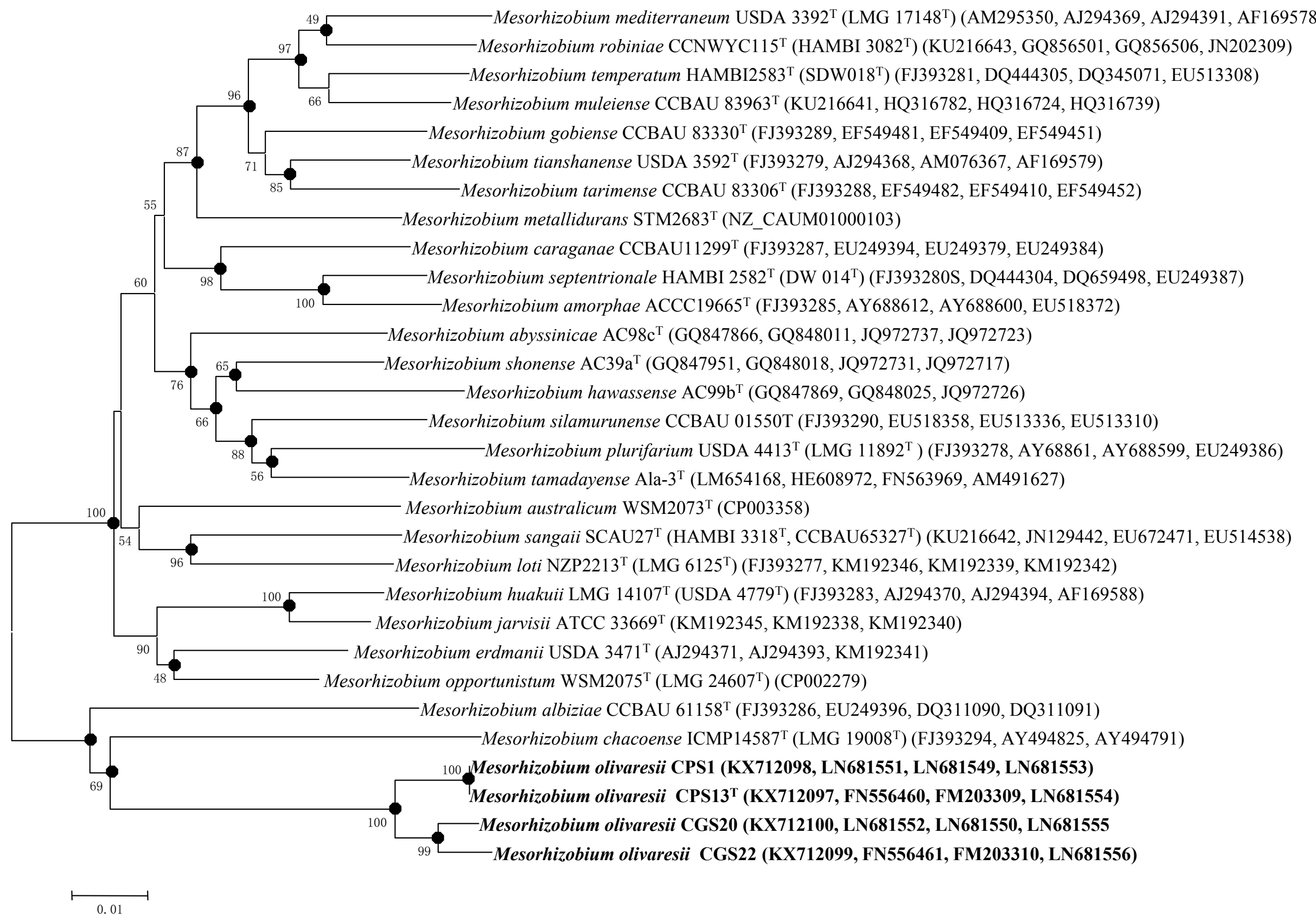


